\title{
STUDI PENAMBAHAN PENGAWET ALAMI PADA NIRA TERHADAP MUTU GULA KELAPA YANG DIHASILKAN
}

\author{
Ade Setyawan $^{(1)}$, dan Retti Ninsix, S.Tp., MP ${ }^{(2)}$ \\ (1) Alumni Teknologi Pangan Faperta UNISI \\ (2) Dosen Teknologi Pangan Faperta UNISI
}

\begin{abstract}
Abstrak
Penelitian ini bertujuan untuk mengetahui jenis bahan tambah alami yang baik di berikan pada nira kelapa terhadap mutu gula kelapa sesuai dengan syarat mutu gula kelapa. Rancangan penelitian yang digunakan dalam penelitian ini yaitu Rancangan Acak Lengkap (RAL) yang terdiri dari 3 perlakuan dan 3 ulangan. dengan pola perlakuan $4 \times 3$ sehingga diperoleh 12 unit per cobaan. Perlakuan yang dilakukan adalah pengaruh penambahan bahan tambah alami pada nira terhadap mutu gula kelapa yang dihasilkan adalah : $\mathrm{A}=$ Kulit kayu Bakau 0,2 gram + Nira Kelapa $(1000 \mathrm{ml}), \mathrm{B}=$ Daun Jambu Biji 0,2 gram + Nira Kelapa $(1000 \mathrm{ml}), \mathrm{C}=$ Teh Bubuk 0,2 gram + Nira Kelapa $(1000 \mathrm{ml}), \mathrm{D}=$ Tanpa Perlakuan + Nira Kelapa $(1000 \mathrm{ml})$. Apabila hasil yang diperoleh berbeda nyata atau $\mathrm{F}$ hitung lebih besar dari F tabel maka dilakukan uji lanjut dengan metode Beda Nyata Jujur (BNJ) pada taraf nyata $5 \%$.
\end{abstract}

Kata Kunci : Gula Kelapa, Nira, Pengawet Alami

\section{PENDAHULUAN}

Tanaman kelapa merupakan tanaman yang multi fungsi, karena mulai dari ujung daun hingga ujung akar kelapa dapat di manfaatkan yang mampu memberi pasokan ataupun distribusi sebagai mata pencaharian sebahagian manusia, bukan hanya buah, batang, daun, akar, bahkan kelapa bisa menghasilkan gula kelapa yang mana kebanyakan orang menyebutnya gula jawa. Gula kelapa ini dihasilkan dari nira atau sebagian orang mengatakannya air legen dari kelapa. (Suwardjono,2001).

Nira kelapa merupakan hasil tanaman kelapa yang tidak boleh dilupakan, yang mana perolehannya didapat atas penyadapan terhadap bagian tertentu pada pohon kelapa yaitu pada bagian mayang bunga kelapa yang masih kuncup ataupun cukup umur. Nira ini mengandung gula, karena itu dapat dijadikan bahan baku pembuatan gula kelapa yang lebih disukai dari pada gula tebu karena mempunyai rasa yang khas (Atjung, 1991).

Di dalam dunia pemasaran produk, gula kelapa ini turut serta dalam dunia perkembangan produk, hal ini di karenakan kebutuhan akan gula kelapa masih sangat menjadi ketergantungan sebahagian orang seperti digunakan sebagai penambah bumbu rempah yang akan dimasak, ramuan obat tradisional, minuman dan makanan kecil seperti dodol, bahkan ada yang dijadikan sebagai bahan baku utama didalam industri makanan, seperti industri kecap, dan idustri rumah tangga lainnya. (Suwardjono, 2001).

Nira adalah media yang subur untuk pertumbuhan mikroorganisme seperti bakteri acetobacter acetic dan sel ragi genus saccharomyces. Pada nira yang mengalami fermentasi secara alami, sel sari dari genus saccharomyces 
akan lebih aktif untuk mensintesa gula (glukosa) dalam menghasilakn alcohol dan gas $\mathrm{CO}_{2}$ (Budiyanto, 2004).

Nira segar mudah sekali mengalami perubahan apabila berada di udara yang terbuka dan juga tidak mendapatkan perlakuan penambahan bahan pengawet. Hasbullah (2001), menyatakkan bahwa kualitas gula antara lain dipengaruhi oleh kualitas nira. Proses penyadapan dan penyimpanan mempengaruhi kesegaran nira karena gula dalam nira sangat mudah terfermentasi, oleh karena itu sering ditambahkan bahan pencegah fermentasi pada saat proses penyadapan. Bahan pencegahan fermentasi ini dapat berasal dari alam dan bahan kimia.

Sampson

dalam

Suwardjono (2001), mengatakan bahwa adanya kandungan sukrosa yang cukup pada nira kelapa di daerah tropis sangat cepat mengalami fermentasi. dengan terjadinya fermentasi akan meyebabkan terjadinya perubahan kualitas nira. Nira kelapa akan mengalami perubahan disebabkan karena terjadinya kontaminasi mikroba-mikroba disekitarnya sehingga akan menurunkan kadar $\mathrm{pH}$ nira kelapa dari itu diperlukan bahan tambah untuk nira kelapa seperti kapur sirih.

Menurut Putranto (1988) dalam Suwardjono (2001), pemberian air kapur pada nira berfungsi sebagai pemelihara pH. Dari itu diperlukan air kapur sebagai pemelihara kesegaran nira kelapa.

Permasalahan yang sering dihadapi para pengrajin nira kelapa yaitu nira hasil penyadapan tidak stabil, sering terjadi kerusakan bila tidak digunakan bahan pengawet atau pemberian air kapur kurang sehingga mempengaruhi gula kelapa yang dihasilkan (Suwardjono, 2001). Berdasarkan pendapat Child 1974 dalam Suwardjono (2001), bahwa bahan yang mengandung tanin dapat menghambat proses fermentasi ataupun kerusakan nira kelapa akibat aktivitas mikroba didalam nira, adapun bahan alami yang mengandung tanin seperti kulit manggis, kulit kayu angin dan lainnya.

Suwardjono (2001), menggunakan bahan tambah pangan didalam nira yang ditambahkan dalam penelitiannya yaitu $50 \mathrm{ml}$ nira kelapa dan 0,01 gram bahan pengawet alami kapur sirih $0,5 \mathrm{ml}$ air, kemudian dibiarkan selama 9 jam ternyata bahwa penggunaan bahan pengawet alami selama 9 jam berpengaruh sangat nyata $(\mathrm{p}<0,01)$ terdapat aktivitas mikroba penyebab perubahan atau penurunan kualitas nira kelapa dan perlakuan yang mempunyai efektivitas lebih baik adalah perlakuan dengan menggunakan bahan pengawet alami kulit manggis. Dengan bahan ini diperoleh hasil $\mathrm{pH}=5,66$, kadar sukrosa $=11,69 \%$, sekor warna $=4$, skor bau $=$ 3,68 , skor rasa $=3,48$.

Berdasarkan hal ini, maka penulis saat ini akan menggunakan pengawet alami lainnya yang mengandung tannin seperti kulit kayu bakau, daun jambu biji, ampas teh. Berdasarkan latar belakang yang sudah dijelaskan bahwa nira kelapa merupakan bahan pembuat gula kelapa yang mudah menagalami perubahan mutu, dan memiliki beberapa permasalahan yang lain seperti dijelaskan pada perumusan masalah sebagai berikut : Penambahan pengawet alami manakah yang berpengaruh sangat baik (Kulit kayu Bakau, ampas teh dan daun jambu biji) pada nira kelapa Sehingga menghasilkan mutu gula kelapa yang baik berdasarkan persyaratan mutu gula kelapa?

Adapun tujuan penelitian ini yaitu untuk mengetahui jenis bahan tambah alami yang baik di berikan pada 
nira kelapa terhadap mutu gula kelapa sesuai dengan syarat mutu gula kelapa.

\section{TINJAUAN PUSTAKA}

\section{Kelapa}

Kelapa (cocos nucifera, L) merupakan salah satu anggota keluarga palmae dikenal sebagai tanaman serba guna karena seluruh bagian tanaman ini bermanfaat bagi kehidupan manusia seperti daun, batang, akar, bunga, buah, tempurung kelapa, air kelapa, dan nira kelapa. Nira kelapa dapat dikembangkan dalam berbagai macam produk olahan. (Suardjono, 2001).

Beberapa negara telah mengembangkan industri pengolahan nira kelapa dan terbukti bahwa pada kondisi- kondisi tertentu, panen kelapa dalam bentuk nira lebih menguntungkan bila dibandingkan dengan panenan kelapa dalam bentuk buah. Salah satu produk olahan nira kelapa adalah gula kelapa Suardjono, (2001). Nira adalah cairan yang disadap dari mayang ( bunga kelapa) yang berumur satu bulan atau belum mekar ( Palungkun, 2003).

Pohon kelapa dapat disadap pada umur 8 tahun serta dapat disadap selama 25-30 tahun. Penyadapan dilakukan sepanjang tahun selama 4 bulan. hasil nira rata- rata sebanyak $2 \mathrm{~kg} /$ hari sadap. Cara penyadapan dilakukan 2-3 kali perhari (Gautara dan wijandi, 1975 dalam Suwarjono, 2001).

\section{Gula Kelapa dan Sifatnya}

Gula kelapa merupakan bahan pangan yang terbuat dari nira kelapa. Nira kelapa adalah cairan manis yang diperoleh dengan melakukan perlakuan khusus terhadap manggar kelapa (spatha) yang belum membuka pada umur tertentu (Setyamidjaja, 1991 di dalam Karseno 2013).

Setiap produk olahan pangan harus memenuhi syarat mutu pangan. begitu juga untuk produk gula kelapa. adapun syarat mutu gula kelapa dapat dilihat pada Tabel 1 .

Tabel 1. Tabel 1. Syarat Mutu Gula Merah ( SNI 013743.1995)

\begin{tabular}{|l|l|l|}
\hline \multicolumn{1}{|c|}{ Keadaan } & \multicolumn{1}{c|}{ Satuan } & \multicolumn{1}{c|}{ Persyaratan (\%) } \\
\hline Bentuk & & Normal \\
\hline Bau & & Normal \\
\hline Rasa & & Normal dan Khas \\
\hline Warna & & Kuning Kecoklatan \\
\hline Bagian yang tidak larut dalam air & $\% \mathrm{bb}$ & Maks 1,0 \\
\hline Air & $\% \mathrm{bb}$ & Maks 10,0 \\
\hline Abu & $\% \mathrm{bb}$ & Maks 2,0 \\
\hline Gula Reduksi & $\% \mathrm{bb}$ & Maks 10,0 \\
\hline Sukrosa & $\% \mathrm{bb}$ & Minimal 77,0 \\
\hline
\end{tabular}

\section{Nira Kelapa}

Nira Kelapa merupakan bagian kelapa yang dimanfaatkan pada bahan dasar pembuatan gula kelapa. Pembuatan gula kelapa secara umum masih bersifat rumahan menggunakan cara tradisional, sehingga sering kali kualitas tidak homogen (Winarno, 1995 dalam Indahyanti, 2014). Nira terdiri dari air, sukrosa, gula reduksi, bahan organik lain dan bahan anorganik. Kandungan gizi yang lengkap pada nira sangat baik untuk pertumbuhan mikroba. Pertumbuhan mikroba 
menyebabkan kerusakan pada nira (Karseno, 2013).

Menurut Eka (2008), salah satu tanda kerusakan nira yaitu terjadinya penurunan nilai $\mathrm{pH}$ yang disebabkan adanya perombakan gula menjadi asam organik oleh mikroba seperti khamir (Saccharomyces sp.) serta bakteri (Acetobacter sp.). Selain itu juga, kontaminasi yang disebabkan oleh mikroba dapat menyebabkan penurunan kadar sukrosa dan peningkatan kadar gula reduksi pada nira.

Hamzah dan Hasbullah (1997) dalam Karseno (2013), menyatakan bahwa khamir Saccharomyces cerevisiae membantu proses hidrolisis sukrosa menjadi gula reduksi di dalam nira. Pencegahan kerusakan nira dapat dilakukan dengan cara menambahkan bahan pengawet nira ke dalam bumbung sebelum digunakan untuk menyadap nira. Umumnya masyarakat menyebut bahan tersebut dengan istilah laru. Laru yang digunakan oleh masyarakat ada dua macam, yaitu laru sintetis dan alami. yang mengandung senyawa tanin Seperti yang di kemukakan oleh Child, (1974) dalam Suardjono (2001), bahwa senyawa yang mengandung tanin dapat menghambat proses fermentasi. Kecuali itu tabung yang dipergunakan untuk menampung nira harus bersih.

Tanin adalah metabolit sekunder tanaman yang bersifat astrigen dengan rasa khas yang sepat. Tanin secara ilmiah didefinisikan sebagai senyawa polipenol yang mempunyai berat molekul tinggi dan mempunyai gugus hidroksil dan gugus lainnya (seperti karboksil) sehingga dapat membentuk kompleks dengan protein dan makromolekul lainnya dibawah kondisi lingkunga tertentu (Isma, 2013 ).
Laru sintetis yang digunakan oleh petani gula kelapa yaitu natrium metabisulfit $\left(\mathrm{Na}_{2} \mathrm{SO}_{2} \mathrm{O}_{5}\right)$ atau sering disebut dengan sulfit atau obat gula. Penggunaan sulfit dalam bahan pangan sebenarnya diperbolehkan apabila tidak melebihi ambang batas yang ditentukan. Batas maksimum penggunaan $\mathrm{Na}$ metabisulfit yang dapat digunakan dalam pengolahan bahan makanan menurut Departemen Kesehatan RI adalah 2 g/kg berat bahan Desrosier dan Desrosier, 1988 dalam Karseno, 2013).

Akan tetapi, masyarakat petani gula kelapa membubuhkan bahan tersebut melebihi ambang batas maksimal sehingga dapat membahayakan kesehatan.

Penggunaan sulfit yang melebihi ambang batas dapat mengganggu kesehatan, yaitu terjadinya gangguan ginjal akibat adanya tumpukan residu (Wicaksono, 2011 dalam Wirawan, 2011). Selain itu, Nurjanah et al. (1991) menyatakan bahwa sulfit dapat mengganggu saluran pernafasan manusia (khususnya penderita asma) dan dapat menyebabkan kematian. Untuk menghindari bahaya yang ditimbulkan oleh penggunaan sulfit yang berlebih maka penggunaan laru sintetis perlu dialihkan pada laru alami.

Nira kelapa pada umumnya bila $\mathrm{pH}$ terlalu tinggi (lebih dari 8) maka hasil gula cenderung berwarna coklat kehitaman akibat kerusakan gula reduksi pada kondisi basa (Purnomo, 2007 dalam Karseno, 2013). Nira memiliki kandungan kimia seperti pH 6-7,5 , brix (\%) > 17 (Marsigit, 2005) dan untuk total padatan 15,2-19,7, sukrosa 12,02$14,85 \%$, Kadar air 88,80 \%, karbohidrat $14,35 \%$, protein $0,1 \%$, lemak $0,17 \%$, abu 0,66 \%, asam askorbat 16,0-30,0 $\mathrm{G} / 100 \mathrm{ml}$ (Badan standar nasional, 1995). 


\section{METODE PENELITIAN}

\section{Bahan}

Bahan-bahan yang digunakan dalam proses pengolahan gula kelapa antara lain nira dari hasil penyadapan saya sendiri. Pengawet alami yang di gunakan (kulit kayu bakau, daun jambu biji, teh bubuk), kapur sirih, air bersih.

Bahan yang digunakan untuk analisa kimia meliputi yaitu Aquades, $\mathrm{Pb}$ asetate, filtrat, $\mathrm{Na}$ Oksalat, $\mathrm{Na}$ Hidrat, Larutan Luffschoorl, Larutan KI, Larutan $\mathrm{H}_{2} \mathrm{SO}_{4}$, Larutan $\mathrm{Na}$ Thiosulfate, $\mathrm{H}_{2} \mathrm{SO}_{4}, \quad \mathrm{Na}_{2} \mathrm{SO}_{4}, \quad \mathrm{HgO}, \quad \mathrm{NaOH}$, $\mathrm{N}_{2} \mathrm{Na}_{2} \mathrm{~S}_{2} \mathrm{O}_{3}$, butiran zink, asam borat, HCL, dan larutan dietil eter.

Alat

Peralatan yang digunakan dalam proses pengolahan gula kelapa adalah timbangan analitik, kompor, Tempat

penampungan nira kelapa, cetakan gula (bambu), kuali, mangkok, sendok, pisau, gelas ukur, termometer. Sedangkan peralatan yang akan digunakan selama penelitian antara lain oven, cawan petri lengkap dengan tutupnya, penjepit cawan, timbangan analitik, desikator, labu elenmeyer, pipet ukur, penyaring.

\section{Rancangan Percobaan}

Rancangan penelitian yang digunakan dalam penelitian ini yaitu Rancangan Acak Lengkap (RAL) yang terdiri dari 3 perlakuan dan 3 ulangan. dengan pola perlakuan $4 \times 3$ sehingga diperoleh 12 unit percobaan. Perlakuan yang dilakukan adalah pengaruh penambahan bahan tambah alami pada nira terhadap mutu gula kelapa yang dihasilkan. Kombinasi perlakuan dapat dilihat pada tabel 2 .

Tabel 3. Kombinasi Perlakuan pada Pengolahan Pengolahan Gula Kelapa

\begin{tabular}{|c|c|c|c|c|}
\hline Ulangan & $\begin{array}{c}\mathrm{A} \\
(\text { Kulit kayu } \\
\text { bakau 0,2 g) }\end{array}$ & $\begin{array}{c}\mathrm{B} \\
(\text { Daun jambu } \\
\text { biji 0,2 g) }\end{array}$ & $\begin{array}{c}\mathrm{C} \\
(\text { Teh bubuk } \\
0,2 \mathrm{~g})\end{array}$ & $\begin{array}{c}\mathrm{D} \\
\text { (Tanpa } \\
\text { perlakuan })\end{array}$ \\
\hline 1 & $\mathrm{~A} 1_{1}$ & $\mathrm{~B} 2_{1}$ & $\mathrm{C} 3_{1}$ & $\mathrm{D} 4_{1}$ \\
\hline 2 & $\mathrm{~A} 1_{2}$ & $\mathrm{~B} 2_{2}$ & $\mathrm{C} 3_{2}$ & $\mathrm{D} 4_{2}$ \\
\hline 3 & $\mathrm{~A} 1_{3}$ & $\mathrm{~B} 2$ & $\mathrm{C} 3_{3}$ & $\mathrm{D} 44_{3}$ \\
\hline
\end{tabular}

Ket : $\mathrm{A}=$ pemberian kulit kayu bakau $0,2 \mathrm{~g}$ pada nira kelapa $1000 \mathrm{ml}$

$\mathrm{B}=$ pemberian daun jambu biji 0,2 g pada nira kelapa $1000 \mathrm{ml}$

$\mathrm{C}=$ pemberian teh bubuk,75 0,2 $\mathrm{g}$ pada nira kelapa $1000 \mathrm{ml}$

$\mathrm{D}=$ tanpa pemberian apapun pada nira kelapa $1000 \mathrm{ml}$

HASIL DAN PEMBAHASAN

\section{Derajat Keasaman ( pH )}

Derajat keasaman $(\mathrm{pH})$ atau derajat keasaman digunakan untuk menyatakan tingkat keasaman atau basa yang dimiliki oleh suatu zat, larutan atau benda. Nira kelapa yang baru menetes dari tongkol bunga kelapa mempunyai $\mathrm{pH}$ netral (lebih kurang 7), tetapi karena kondisinya, maka cairan itu mudah mengalami kontaminasi mikroba disekitarnya, sehingga terjadi penurunan pH (Frazier, 1979 dalam Suwardjono, 2001).

Hasil pengamatan menunjukkan bahwa perlakuan persentase kulit kayu bakau nira kelapa yang dilakukan pengamatan selama 15 jam menunjukan $\mathrm{pH}$ 5,7, sedangkan perlakuan dengan penambahan pengawet alami daun jambu biji terhadap nira kelapa yang 
dilakukan pengamatan selamat 15 jam menunjukan $\mathrm{pH}$ 6,1 dan perlakuan dengan penambahan pengawet alami teh bubuk terhadap nira kelapa yang dilakukan pengamatan selama 15 jam menunjukan $\mathrm{pH}$ 6,6 dan pada pengamatan dengan tanpa perlakuan hanya pemberian air kapur terhadap nira kelapa dengan dilakukan pengamatan selama 15 jam menunjukan $\mathrm{pH}$ 5,6. Data pengamatan terhadap nilai $\mathrm{pH}$ masingmasing perlakuan dapat dilihat di tabel 2 .

Tabel 2. Hasil Pengamatan Nilai pH terhadap Masing-Masing Perlakuan Penambahan Pengawet Alami

\begin{tabular}{|c|c|l|l|l|l|}
\hline \multirow{2}{*}{ No } & \multirow{2}{*}{ Jam } & \multicolumn{5}{|c|}{ Pengamatan } \\
\cline { 3 - 6 } & & $\begin{array}{c}\text { Kulit Kayu } \\
\text { bakau }\end{array}$ & $\begin{array}{c}\text { Daun } \\
\text { Jambu biji }\end{array}$ & $\begin{array}{c}\text { Teh } \\
\text { bubuk }\end{array}$ & $\begin{array}{c}\text { Air } \\
\text { kapur }\end{array}$ \\
\hline $\mathbf{1}$ & $\mathbf{1}$ & 6,8 & 7,0 & 7,0 & 6,2 \\
\hline $\mathbf{2}$ & $\mathbf{3}$ & 6,6 & 6,9 & 7,0 & 6,2 \\
\hline $\mathbf{3}$ & $\mathbf{5}$ & 6,4 & 6,9 & 6,9 & 5,9 \\
\hline $\mathbf{4}$ & $\mathbf{7}$ & 6,3 & 6,7 & 6,8 & 5,8 \\
\hline $\mathbf{5}$ & $\mathbf{9}$ & 6,0 & 6,4 & 6,8 & 5,8 \\
\hline $\mathbf{6}$ & $\mathbf{1 1}$ & 5,9 & 6,2 & 6,7 & 5,7 \\
\hline $\mathbf{7}$ & $\mathbf{1 3}$ & 5,8 & 6,2 & 6,6 & 5,6 \\
\hline $\mathbf{8}$ & $\mathbf{1 5}$ & 5,7 & 6,1 & 6,6 & 5,6 \\
\hline
\end{tabular}

Dari tabel 2 menjelaskan bahwa pengolahan nira kelapa setelah dilakukan pengamatan terhadap nilai $\mathrm{pH}$ nira selama 15 jam pengamatan setelah itu barulah dilakukakn pengolahan, berdasarkan pengukuran $\mathrm{pH}$ nira kelapa selama 15 jam menunjukan terjadinya penurunan nilai $\mathrm{pH}$ nira kelapa awal penampungan sampai 15 jam pengendapan nira. Nilai $\mathrm{pH}$ terendah terdapat pada perlakuan dengan penambahan bahan pengawet alami kapur sirih pada nira kelapa, namun pada perlakuan ini menunjukan angka yang relative stabil, penurunan kadar $\mathrm{pH}$ tidak secara signifikan. Dan nilai $\mathrm{pH}$ tertinggi pada perlakuan penambahan pengawet alami teh bubuk, di ikuti oleh pengawet alami daun jambu biji, dan perlakuan dengan penambahan bahan pengawet alami dengan kulit kayu bakau, dan yang terakhir perlakuan dengan penambahan air kapur sirih. pada dasarnya air kapur sirih merupakan penyetabil atau pemelihara kadar $\mathrm{pH}$ (Putranto, 1988 dalam Suwardjono 2001).
Beberapa faktor yang dapat mempengaruhi kestabilan $\mathrm{pH}$ yaitu salah satunya disebabkan adanya gangguan seragga pada saat proses penampungan nira dilakukakn. Seperti yang dikemukakan Suwardjono, (2001) bahwasannya faktor yang dapat mempengaruhi proses fermentasi adalah kuranng bersihnya tanaman, iklim yang tidak baik, tabung bambu yang tidak bersih, aktivitas seranggga, penggunaan bubur kapur yang terlalu sedikit dan jasad renik.

\section{Kadar Air}

Pengukuran kandungan air yang berada dalam bahan ataupun sediaan yang dilakukan dengan cara yang tepat diantaranya cara titrasi, destilasi, atau gravimetri yang bertujuan memberikan batasan minimal atau rentang tentang besarnya kandungan air dalam bahan, dimana nilai maksimal atau rentang yang diperbolehkan terkait dengan 
kemurniaan dan kontaminasi (Dirjen POM, 2000).

Standar kadar air merupakan salah satu parameter kritis yang harus diperhatikan, karena mempengaruhi daya simpan produk. Adanya air dalam bahan pangan merupakan media yang baik bagi pertumbuhan mikroorganisme terutama untuk produk kering adalah tumbuhnya kapang dan khamir.

Hasil analisa statistik Penambahan pengawet alami oada nira kelapa dengan konsentrasi berbeda terhadap kualitas gula kelapa dengan kadar air yang dihasilkan dapat dilihat pada Tabel 3 .

Tabel 3. Rata-Rata Kadar Air Gula Kelapa Yang Dihasilkan Berdasarkan Perlakuan Penambahan Pengawet Alamipada Nira Kelapa.

\begin{tabular}{|c|ccc|}
\hline Perlakuan & \multicolumn{3}{|c|}{ Kadar Air \% } \\
\hline A & 9.8657 & a \\
\hline B & 7.7998 & b \\
\hline C & 6.5953 & c \\
\hline D & 4.9374 & d \\
\hline
\end{tabular}

Keterangan :Perlakuan A : Kulit Kayu Bakau, B : Daun Jambu Biji, C : Teh Bubuk, D: Air Kapur Sirih. Angka-angka pada jalur yang sama diikuti oleh huruf kecil yang sama menunjukkan berbeda tidak nyata menurut Uji Beda Nyata Terkecil pada taraf 5\%.

Tabel 3 memperlihatkan bahwa kadar air gula kelapa yang dihasilkan berdasarkan perlakuan beberapa penambahan pengawet alami dan berdasaarkan uji lanjut BNJ dengan taraf $5 \%$ menunjukan bahwa kesemua perlakuan $\mathrm{C}$ dengan $\mathrm{A}$ berbeda nyata pada taraf $5 \%$, A dengan $\mathrm{B}$ berbeda nyata pada taraf $5 \%$ dan begitu juga $B$ dengan $\mathrm{D}$ saling berbeda nyata pada taraf 5\%. Terlihat bahwa kadar air tertinggi pada perlakuan A yaitu 9.8657 $\%$, dan kadar air terendah terdapat pada perlakuan D yaitu $4.9374 \%$, hal ini diduga karena sifat dari kapur sirih yang cendrung memiliki elektrolit kuat sehingga mudah larut dalam air dan ion $\mathrm{Ca}$ akan mudah terabsorbsi dalam jaringan bahan (Purnomo, 1992 dalam Rekna 2012), terlebih penambahan air kapur sirih pada perlakuan D yaitu (o,2 gram $+2,5 \mathrm{ml})$ lebih banyak dari perlakuan $\mathrm{A}, \mathrm{B}$ dan $\mathrm{C}$, yang hanya ditambahkan air kapur dengan jumlah 2,5 ml untuk 1 liter nira kelapa. Disamping itu, kadar air pada perlakuan $\mathrm{A}, \mathrm{B}$ dan $\mathrm{C}$, sedikit lebih tinggi dari perlakuan penambahan air kapur sirih pada nira kelapa, hal ini dikarenakan penggunaan penambahan bahan pengawet alami berupa kulit kayu bakau, daun jambu biji, dan bubuk teh terlebih dahulu di ektrak menggunakan air sehingga kandungan air yang terdapat pada gula kelapa pada perlakuan penambahan kulit kayu bakau, daun jambu biji, bubuk teh, mempunyai kandungan air yang lebih tinggi dari perlakuan dengan penambahan pengawet alami air kapur sirih pada nira kelapa. Sedangkan secara umum kadar air gula kelapa dari masing- masing perlakuan masih berada di rata-rata yang ditetapkan oleh Badan Standar Nasional Indonesia Tahun 1995 tentang persyaratan mutu gula kelapa dengan kadar air maksimal hanya $10 \%$

Air merupakan komponen penting dalam bahan makanan karena air dapat mempengaruhi penampakan, tekstur, serta cita rasa makanan. Kandungan air dalam bahan makanan menentukan acceptability, kesegaran, dan daya tahan bahan tersebut (Winarno, 2002). Oleh karena itu, dilakukan analisa kadar air dengan 
tujuan untuk mengetahui jumlah air yang terdapat pada produk gula kelapa dengan penambahan bahan pengawet alami yang dihasilkan. Pengukurannya dilakukan dengan menggunakan cara basis basah. Jumlah kadar air dalam produk gula kelapa akan berpengaruh terhadap tekstur maupun citarasanya dan juga dengan umur simpan gula kelapa.

\section{Gula Sukrosa}

Hasil pengamatan terhadap kadar sukrosa akibat penambahan bahan pengawet alami pada nira kelapa terhadap mutu gula yang berkisar antara 62.741-66.487\%. Pengaruh penambahan pengawet alami yang berbeda terhadap kadar sukrosa ditunjukkan pada tabel 4 .

Tabel 4. Rata-Rata Kadar Gula Sukrosa Gula Kelapa Yang Dihasilkan Berdasarkan Perlakuan Penambahan Pengawet Alami.

\begin{tabular}{|c|c|}
\hline Perlakuan & Gula Sukrosa \% \\
\hline D & $66.487 \mathrm{a}$ \\
\hline C & $64.592 \quad$ b \\
\hline B & 63.862 bc \\
\hline A & $62.741 \quad$ c \\
\hline
\end{tabular}

Keterangan :Perlakuan A : Kulit Kayu Bakau, B : Daun Jambu Biji, C : Teh Bubuk, D: Air Kapur Sirih. Angka-angka pada jalur yang sama diikuti oleh huruf kecil yang sama menunjukkan berbeda tidak nyata menurut Uji Beda Nyata Terkecil pada taraf 5\%.

Tabel 4 memperlihatkan bahwa kadar gula sukrosa gula kelapa yang dihasilkan berdasarkan perlakuan penambahan pengawet alami yaitu perlakuan $\mathrm{D}$ berbeda nyata terhadap perlakuan C, B , dan A pada taraf 5\%, dan perlakuan $\mathrm{c}$ berbeda nyata terhadap perlakuan $\mathrm{A}$, tetapi perlakuan $\mathrm{C}$ berbeda tidak nyata dengan $\mathrm{B}$, dan perlakuan $\mathrm{B}$ juga berbeda tidak nyata dengan perlakuan A.

Kadar gula sukrosa pada gula kelapa yang dihasilkan pada semua perlakuan masih dibawah rata- rata yang telah di tetapkan oleh badan standar nasional indonesia tahun 1995 tentang persyaratan mutu gula kelapa dengan kadar sukrosa minimal $77 \%$. Hal ini dikarenakan penambahan pengawet alami yang dibubuhkan pada nira dalam jumlah yang sedikit hanya 0,2 gram / $1000 \mathrm{ml}$ nira kelapa sehingga gula kelapa yang dihasilkan mempunyai kadar sukrosa yang rendah yang belum mencapai rata- rata yang telah di tetapkan oleh badan standar nasional Indonesia tahun 1995 tentang mutu gula kelapa. Pernyataan ini didukung oleh Annisa 2013 yang menyatakan bahwa semakin tinggi persentase campuran pengawet alami terhadap total laru alami, kadar sukrosa semakin tinggi. kadar sukrosa berkaitan dengan kadar gula reduksi dan $\mathrm{pH}$ nira. Sukrosa semakin tinggi artinya gula reduksi semakin rendah.

Dari tabel 4 menunjukan bahwa perlakuan yang paling tinggi kadar gula sukrosanya yaitu pada perlakuan penambahan air kapur sirih dengan total gula sukrosa $66.487 \%$, disusul dengan menggunakan perlakuan penambahan teh bubuk dengan kadar gula sukrosa total $64.592 \%$, dan disusul dengan perlakuan penambahan daun jambu biji dengan kadar sukrosa total $63.862 \%$, dan perlakuan dengan kadar gula sukrosa terendah adalah perlakuan dengan penambahan bahan pengawet alami kulit 
kayu bakau dengan total kadar gula sukrosa $62.741 \%$.

\section{KESIMPULAN DAN SARAN}

\section{Kesimpulan}

Kesimpulan yang diperoleh setelah melakukan penelitian adalah : berdasarkan analisa kimia, perlakuan yang menghasilkan gula kelapa yang terbaik pada perlakuan dengan penambahan kapur sirih pada nira kelapa dengan nilai $\mathrm{pH}$ 5,6 yang dilakukan perlakuan selama 15 jam, dengan menghasilkan kadar air sebesar $4.9374 \%$, gula sukrosa 66.487 . Perlakuan terbaik kedua yaitu dengan penambahan bubuk the pada nira kelapa yang menghasilkan gula kelapa dengan kandungan air sebesar 6.5953 dan kadar gula sukrosa 64.592, perlakuan dengan penambahan bahan pengawet alami daun jambu biji pada nira kelapa menghasilkan gula kelapa dengan kadar air 7.7998 dan kadar sukrosa 63.862, dan perlakuan dengan kadar air tertinggi yaitu pada perlakuan dengan penambahan bahan pengawet alami kulit kayu bakau pada nira kelapa dengan menghasilkan gula kelapa yang memiliki kandungan air sebesar 9.8657 dan kadar gula sukrosa terendah pula yaitu 62.741.

\section{Saran}

Penelitian ini hanya dibatasi pada pengamatan adanaya perubahan fisik nira kelapa dan perubahan kimiawi dan sensori pada gula kelapa yang dihasilkan. satu hal yang menarik apabila ada yang berminat untuk melanjutkan penelitian ini dengan pengamatan secara mikrobiologis terhadap keberadaan mikroba yang menyebabkan kerusakan nira kelapa, ataupun studi penyimpanan gula kelapa yang telah dihasilkan.

\section{DAFTAR PUSTAKA}

Suardjono. 2001. Pengaruh Penggunaan Bahan Pengwet Alam terhadap Nira Kelapa yang Digunakan untuk Pembuatan Gula Kelapa di Daerah Istimewa Yogyakarta. Laporan Penelitian. Universitas Terbuka.

Atjung. 1991. Tanaman Pengolahan Pangan Nabati Tepat Guna. Jakarta ; Akademik Presindo.

Marsigit,W. 2005. Penggunaan Bahan Tambah pada Nira dan Mutu Gula Aren yang Dihasilkan di Beberapa Sentra Produksi di Bengkulu. Jurnal Penelitian UNIB, Vol. XI, No 1, Maret 2005,Hlm. 42- 48.

Martono,Y., Gunawan,M., Dewi,L. 2010. Kadar Fenolik Total dan Aktivitas Antioksidan dari Asam Fenolat Ampas Teh Hijau. Universitas Kristen Satya Wacana. Salatiga.

Indahyanti,E., Kmulyan,B., Ismuyanto,B. 2014. Optimasi Konsentrasi Garam Bisulfit Pada Pengendalian Kualitas Nira Kelapa. Jurnal Penelitian Saintek, Vol. 19, Nomor 1, April 2014. Universitas Brawijaya Malang.

Hamidah,S. 2006. Rendemen dan Kadar Tanin Kulit Kayu Bakau (Rhizophora Mucronata Lamck) dari Daerah Takisung. Jurnal Hutan Tropis Borneo No. 18, Maret 2006. Universitas Lambung Mangkurat. Kalimantan Selatan.

Rosidah dan Afizia,W,M. 2012. Potensi Ekstrak Daun Jambu Biji sebagai Antibakterial untuk Menanggulangi Serangan Bakteri Aeromonas Hydrophila pada Ikan Gurame (Osphronemus Gouramy Lacepede). Jurnal Akuatika Vol. III No. 1/ Maret 2012 (19-27) ISSN 0853-2523. Universitas Padjadjaran. 
Karseno, Setyawati,R dan Haryanti,P.2013. Penggunaan Bubuk Kulit Buah Manggis sebagai Laru Alami Nira terhadap Karakteristik Fisik dan Kimia Gula Kelapa. Laporan Penelitian. Jurusan Teknologi Pertanian, Fakultas Pertanian, UNSOED.

Sukoyo,A. Argo,B,D. Yulianingsih,R. 2014. Analisis Pengaruh Suhu Pengolahan dan Derajat Brix terhadap Karakteristik Fisikokimia dan Sensoris Gula Kelapa Cair dengan Metode Pengolahan Vakum. Jurnal Bioproses Komoditas Tropis Vol. 2 No.2, Nopember 2014. Fakultas Teknologi Pertanian - Universitas Brawijaya.

Palungkun,R. 2003. Aneka Produk Olahan Kelapa. Jakarta : Penebar swadaya.

Mappalejju,Z,K. 2015. Manfaat Ampas Teh. Karya Ilmiah.http:// Diakses Hari Kamis, 29 januari 2015.

Andini,N.2006. Info Kabupaten Indragiri Hilir. http://www.academia.edu /8554343/Kabupaten_Indragiri_Hil ir_Kamis. Diakses kamis, 12 Oktober 2006.

Widianto, R, K.2011. Proses Pembuatan Gula Kelapa. http://www. juragankalapa.blogspot. diakses hari 12 September 2015.

Annisa.H.F.2013. Pengaruh Campuran Ekstrak Sirih Hijau dan Ekstrak Kulit Buah Manggis dengan Larutan Kapur pada Nira Kelapa terhadap Kualitas Gula Kelapa. Skripsi. Universitas Jendral Sudirman. Program Studi ITP.

A.A. Azis. 2013. Pengaruh Penambahan Pati Sagu dengan Konsentrasi Berbeda terhadap Kualitas Nugget Tempe. Skripsi. Universitas Islam Indragiri. Program Studi Teknologi Pangan.
Noriko.N. 2013. Potensi Daun Teh ( camellia sinensis) dan Daun Anting- Anting Acalypa indica L. dalam Menghambat Pertumbuhan Salmonella Typhi. Jurnal Al-azhar Indonesia seri Sains dan Teknologi, Vol.2, No.2, September 2013.

Karseno.Retno.s. Pepita H. 2013. Penggunaan Bubuk Kulit Buah Manggis sebagai Laru Alami Nira terhadap Karakteristik Fisik dan Kimia Gula Kelapa. Program Studi Ilmu dan Teknologi Pangan, Jurusan Teknologi Pertanian, Fakultas Pertanian UNSOED.

Sukardi.Mulyarto.A.R. Safera.W. 2007. Optimalisasi Waktu Ekstraksi terhadap Kandungan Tannin pada Bubuk Ekstrak Daun Jambu Biji (psidii folium) serta Biaya Produksinya. Universitas Brawijaya. Jurnal Teknologi Pertanian, Vol.8 No.2 88- 94.

Poedjirahajoe.E. Widyorini.R. Ni Putu Mahayani.D. 2011. Kajian Ekosistem Mangrove Hasil Rehabilitasi pada Berbagai Tahun Tanam untuk Estimasi Kandungan Tanin di Pantai Utara Jawa Tengah. Jurnal Ilmu kehutanan vol. V No. 2.

Wartono.2015. Kajian ZAT Pewarna Alami(ZPA) dari Ekstrak Kulit Kayu Bakau (Rhizopora Sp.) sebagai Pewarna Kain Ramah Lingkungan. Skripsi. Program Studi Kimia Fakultas Sains dan Teknologi Universitas Islam Negeri Sunan Kalijaga. Yogyakarta. 